\title{
Swedish farmers attitudes, expectations and fears in relation to growing genetically modified crops
}

\author{
Anna LEHRMAN ${ }^{1 *}$ and Katy JOHNSON ${ }^{2}$ \\ 1 Department of Ecology, Swedish University of Agricultural Sciences, P.O. Box 7044, 750 07, Uppsala, Sweden \\ 2 The University of Southampton, Bassett Crescent East, Highfield, Southampton, SO16 7PX, UK
}

This study evaluates a survey about Swedish farmers' attitude towards genetically modified (GM) crops, and their perception concerning potential benefits and drawbacks that cropping of an insect resistant (IR) GM variety would involve. The questions were "tick a box" choices, included in a yearly omnibus survey sent to 1000 Swedish farmers (68\% response rate). The results showed that a majority of the farmers were negative, although almost one third claimed to be neutral to GM crops. The farmers recognized several benefits both in terms of agricultural production and for the environment, but they were also highly concerned about the consumers' unwillingness to buy GM products. Farmers perceived an increase in yield, but nearly as many farmers thought that there would be no benefits with growing an IR GM crop. Several differences in hopes and concerns of the farmers surveyed were revealed when they were divided in positive, neutral and negative groups. Farmers negative to GM were more concerned than positive farmers about IR GM crops being dangerous for humans, livestock or other organisms to consume. GM-positive farmers seemed to be most concerned about potential problems with growing a marketable crop and expensive seeds, but saw a reduced health risk to the grower, due to less use of pesticides, as a possible benefit. The results among the GM-neutral farmers were in most cases closely related to the positive farmers' choices, implying that they believe that there are advantages with growing an IR GM crop, but also fear potential drawbacks. This general uncertainty about GM IR crops may prevent them from accepting the new technology.

Keywords: farmers / GM crop / attitude / insect resistance / drawback / advantage

\section{INTRODUCTION}

In 2006, 10.3 million farmers worldwide grew genetically modified (GM) crops on 102 million hectares of land, of which 32\% were insect resistant (IR) crops (James, 2006). At present, the only approved commercial IR GM crop in the European Union (EU) is maize transformed with a protein from Bacillus thuringiensis (Bt), resistant to the European corn borer (Ostrinia nubilalis) and the Mediterranean stemborer (Sesamia nonagroides). Seven countries in the EU cultivated $B t$-maize commercially in 2006, mainly for animal feed, but also for bio-ethanol production (Brookes, 2007). Spain was the largest grower with 53667 ha planted in 2006, followed by France (5200 ha), Czech Republic (1290 ha), Portugal (1240 ha), Germany (950 ha), and Poland and Slovakia (both 30 ha) (James, 2006).

Potential risks with growing GM plants are dependent on the crop, the transformed trait, and the environment where it is grown. When considering IR GM crops, the

* Corresponding author: anna.lehrman@ekol.slu.se major concerns raised in the literature are gene flow to relatives (wild or crops), negative effects on non-target organisms, food safety, and development of resistant insect populations (Conner et al., 2003; Shelton et al., 2002; Weaver and Morris, 2005). These factors have a direct impact at the farm level, but are equally a concern of conventional farm practices that are heavily reliant on the use of insecticidal sprays. In addition to the environmental issues associated with GM crops, there is also the question of whether economic benefits will be realized, for example, if GM crops actually reduce insecticidal reliance or increase farmers' yields in comparison to their conventional counterparts. So far, the scientific reports are generally positive, and the first ten years of commercial growing of GM crops are calculated to have reduced pesticide spraying by 224 million $\mathrm{kg}$ (active ingredient) (Brookes and Barfoot, 2006). The change in pesticide usage, yield and net return vary with the crop and trait transformed, and in Europe planting $B t$-maize has resulted in average yield benefits of at least $10 \%$ with an improvement of profitability between 12 to $21 \%$ (Brookes, 2007). 


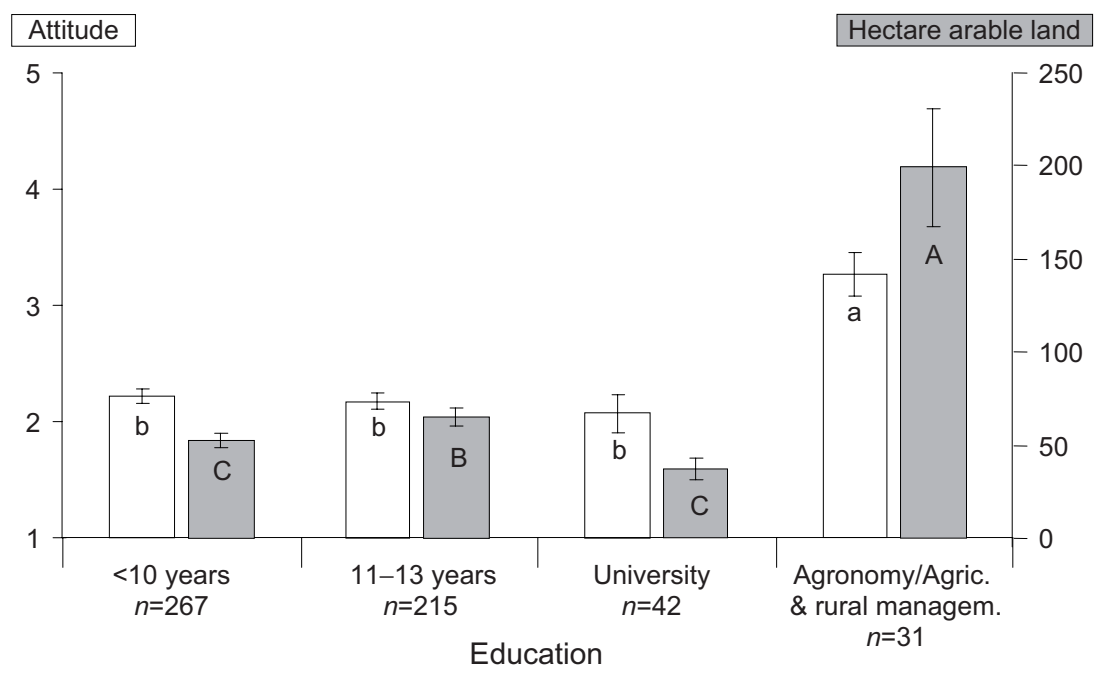

Figure 1. Difference in mean $( \pm$ S.E. $)$ attitude towards GM crops $(1=$ very negative, $5=$ very positive $)$, and acreage of arable land between farmers grouped according to level and type of education $(<10$ years $=$ mandatory $)$. Different letters indicate significant differences between categories for each variable (Kruskal-Wallis $P<0.05$ ).

Two reports on farmers' experience with growing GM crops were conducted in the United States (US) (Pilcher et al., 2002; Wilson et al., 2005). Pilcher et al. (2002) found the main reason for farmers planting $B t$-maize was to reduce yield losses, with farmers reporting on average higher yields, less need for scouting, and reduced use of pesticide. US farmers expected that the primary benefit would be less insecticide exposure for them and a reduction of insecticides in the environment (Wilson et al., 2005). However, the growers were worried about their ability to sell the harvest. They also expressed concerns of additional technology fees associated with buying transgenic seed.

The decision by the Swedish meat industry association (KCF) in 2005 to allow GM soy meal as feed in Swedish meat production (http://www.atl.nu/Article.jsp?article=32049), confronts the farmers with the ability to purchase GM feed for their animals, and they may in the near future have to decide whether or not to apply the technology. We would therefore argue that there has never been a more pertinent time to assess Swedish farmers' attitudes towards commercially cultivating GM crops on their farms. While consumer attitudes regarding GM food have been evaluated in several studies (Anderson et al., 2006; Gaskell et al., 2000; Hornig Priest, 2000; Magnusson and Koivisto Hursti, 2002; Poortinga and Pidgeon, 2006) the attitudes of farmers have attracted far less attention, especially in Europe.

Previous surveys in Sweden have concerned farmer's general attitudes towards GM crops (Sveriges Lantbruk, 2003) but none have asked what the concerns and expec- tations are of this new technology. We surveyed not only the Swedish farmers' attitudes to GM crops, but also their perceptions concerning potential advantages and disadvantages of growing IR GM crops. We also considered the influence of educational level, age, and farm size on their attitudes towards GM crops.

\section{RESULTS}

Of the selected farmers, 121 had quit farming, sold their land, or were leasing out their farm and 17 were incapacitated. Of the remaining 862 farmers, 277 did not answer, resulting in a response rate of $68 \%$.

\section{Attitude towards GM crops}

Of the farmers in our study, $56.7 \%$ were negative (negative $24.8 \%$; very negative $31.9 \%$ ), while only $12.7 \%$ were positive (positive $10.7 \%$; very positive $2.0 \%$ ). However, $30.6 \%$ were neutral, leaving a third of the farmers to form a strong opinion about IR GM crops.

Attitudes to GM crops did not differ significantly between age groups $\left(\chi^{2}=2.58, \mathrm{df}=4, P=0.63\right)$, neither did attitude correlate with educational level $\left(\mathrm{r}_{K}=0.05\right.$, $n=561, P=0.15)$. However, farmers who had studied to degree level in agronomy or agriculture and rural management were significantly more positive towards GM crops compared to the other groups $\left(\chi^{2}=27.49, \mathrm{df}=1\right.$, $P<0.0001$; Fig. 1). These farmers also owned larger 


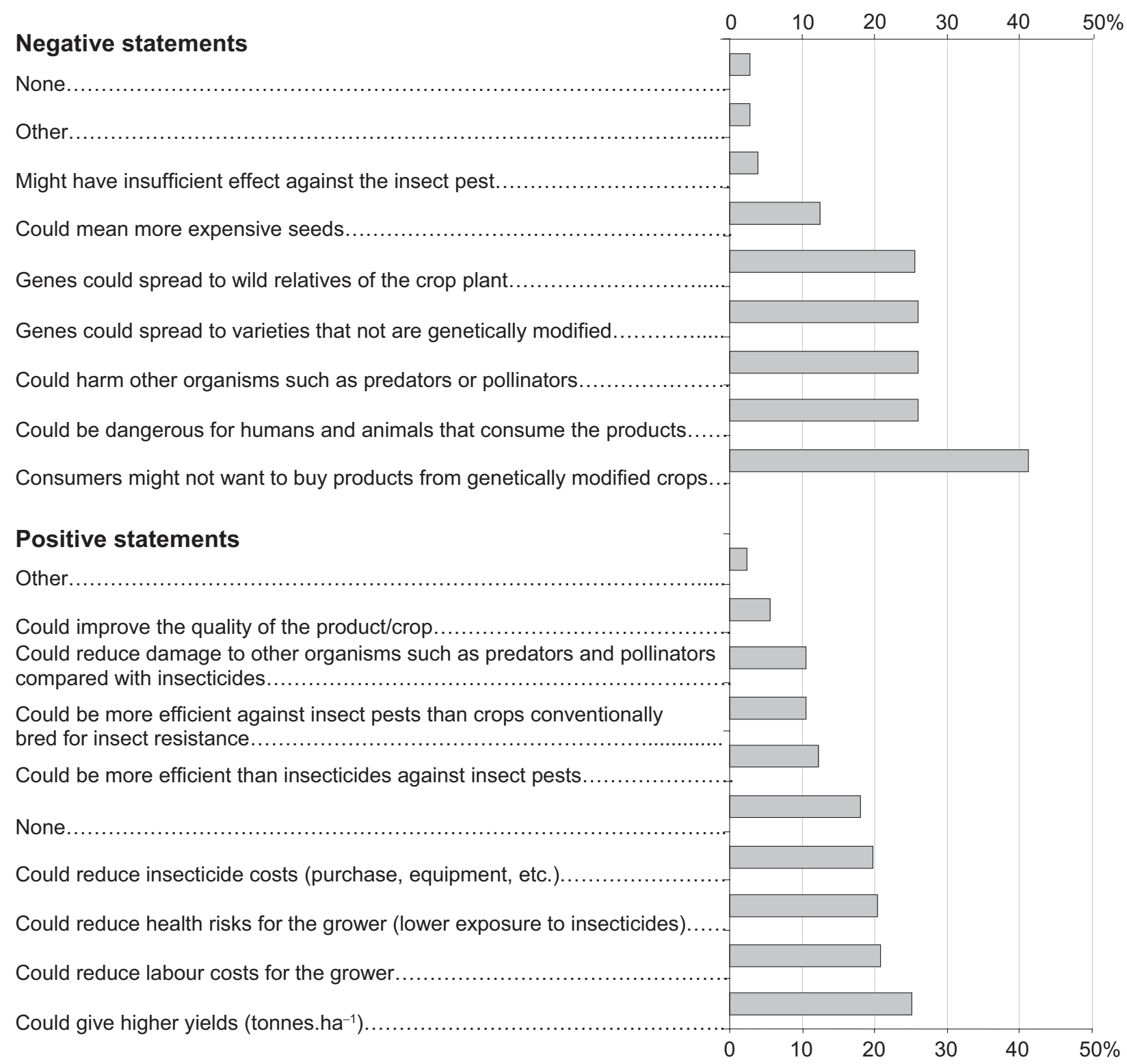

Figure 2. Percentage of farmers selecting the different positive and negative statements as answers to "There are now plant varieties that have been made resistant to certain insects by genetic modification. What do you think would be the most important disadvantages or drawbacks of growing such crops?" and "What do you think would be the most important advantages or benefits of growing such crops?" Each farmer was allowed to select two statements from each group. The statements are presented from least to most often selected by all farmers.

farms, and there was also a significant correlation between farm size and a more positive attitude $\left(\mathrm{r}_{K}=0.20\right.$, $n=561, P<0.0001$ ), with those farmers who owned larger sized farms being more positive about IR GM crops.

\section{Advantages and drawbacks}

In terms of the perceived advantages of growing a crop with a genetic modification for IR, the most selected statement was a potential increase in yield (Fig. 2). 
The potential for GM crops to reduce labor costs, health risk for the farmer, and insecticide costs was also considered important potential benefits of the technology. However, almost an equal proportion of farmers believed that there would be no benefits from growing IR GM crops (Fig. 2).

Among the possible drawbacks or risks, the negative attitude among consumers towards GM crops was, by far, the most selected statement (Fig. 2). The risk of the products being harmful for humans and livestock to consume, the potential for harm to other organisms, and the potential for IR GM-crop genes spreading to non-GM varieties or wild relatives were also frequently selected.

When considering how the farmer attitude in general, positive/neutral/negative, toward GM crops related to their views on the benefits and drawbacks of GM IR crops, several differences in selection of statements appear (Fig. 3). Farmers who were in general positive towards GM crops were more likely to see the potential benefits of reduced health risks for themselves than the farmers who were neutral or negative $\left(\chi^{2}=4.51, \mathrm{df}=1\right.$, $P=0.034$ and $\chi^{2}=16.74$, df $=1, P<0.0001$ respectively). Farmers positive or neutral towards GM crops had higher expectations for reduced insecticide costs than negative farmers $\left(\chi^{2}=4.65, \mathrm{df}=1, P=0.031\right.$ and $\chi^{2}=10.37$, df $=1, P=0.0013$ respectively), and positive farmers were more likely to identify the potential for improvement in crop quality $\left(\chi^{2}=10.08\right.$, df $=1$, $P=0.0015)$ than farmers with a negative attitude toward GM crops. Significantly more of the neutral than negative farmers believed the IR GM crops could reduce damage to other organisms $\left(\chi^{2}=6.04, \mathrm{df}=1, P=0.014\right)$ and have more efficient resistance $\left(\chi^{2}=4.83\right.$, df $=1$, $P=0.028$ ) compared to conventional crops bred for IR, but did not see the personal health benefits or economic benefits the positive farmers perceived. Most of the farmers negative to GM-crops perceived there to be no potential benefits from growing an IR GM crop (Fig. 3).

When looking at the potential drawbacks or risks, farmers negative towards GM crops were significantly more concerned by the potential harm to humans and livestock feeding on IR GM products than positive and neutral farmers $\left(\chi^{2}=20.37\right.$, df $=1, P<0.0001$ and $\chi^{2}=22.07, \mathrm{df}=1, P<0.0001$ respectively). The same holds true for the potential harm IR GM crops might cause to other organisms such as predators and pollinators (negative farmers in relation to: positive farmers $\chi^{2}=5.97, \mathrm{df}=1, P=0.015 ;$ neutral $\chi^{2}=6.87, \mathrm{df}=1$, $P=0.0087)$. Positive farmers, on the other hand, were significantly more concerned by the consumers' negative attitude $\left(\chi^{2}=7.03, \mathrm{df}=1, P=0.008\right)$, the risk of more expensive seeds $\left(\chi^{2}=34.96\right.$, df $\left.=1, P<0.0001\right)$ and insufficient effect by the IR GM crop on the target pest $\left(\chi^{2}=7.25, \mathrm{df}=1, P=0.0071\right)$ than their colleagues with negative attitude.

\section{Correlations between statements}

The principal components analysis (PCA) biplot (Fig. 4) shows the relationship of selected statements and attitude, revealing four clusters of statements which also are shown in the correlation matrix (Tab. 1). Four statements (three to do with the benefits, one the drawbacks) and a more positive attitude to GM crops are positively correlated with PCA 1 (circle 1 in Fig. 4 and Tab. 1). This means that the farmers who had a more positive attitude towards GM crops would be likely to hold the opinions that IR GM crops have the potential to reduce insecticide costs, reduce the health risks to the grower and reduce damage to other organisms compared to insecticides. These farmers were also likely to be concerned about the potential for IR GM crops to be more expensive in terms of seed costs.

Three statements relating to the lack of benefits and the toxicity of the crops correlate negatively with PCA 1 (circle 2 in Fig. 4). Therefore, these are statements that farmers who were negative towards IR GM crops identified with. These included the view that IR GM crops provide no benefits, the crops could be dangerous for humans and livestock to consume and could also be harmful to other organisms.

There are two other clusters of statements (circles 3 and 4 in Fig. 4), which do not correlate with any general GM attitude held by the farmers. Circle 3 reveals that a group of farmers believe that IR GM crops could potentially produce higher yield, but are at the same time concerned about consumer acceptance of these crops (Tab. 1), while circle 4 suggests a concern with gene flow to both wild relatives and non GM crops. This opposite position on PCA axis 2 would suggest that, in the context of our study, farmers who believe in potential yield increase are most concerned about consumer acceptance of GM crops but are unlikely to raise concerns about gene flow and vice-versa.

\section{DISCUSSION}

The farmers in our study were predominately negative to GM crops $(57 \%)$ and the fact that a large proportion of farmers did not identify any benefits resulting from the adoption of IR GM crops further illustrates their negativity towards the technology. When considering the selected statements about IR GM crops in relation to the general opinion expressed by the farmers, a number of patterns emerge which go towards explaining the farmers' attitudes (illustrated in Fig. 3 and on axis 1 of the PCA diagram Fig. 4). Farmers who were positive towards IR GM crops predominantly identified statements linked to the economic viability of the crops. They were more 
Farmers expectations on genetically modified crops

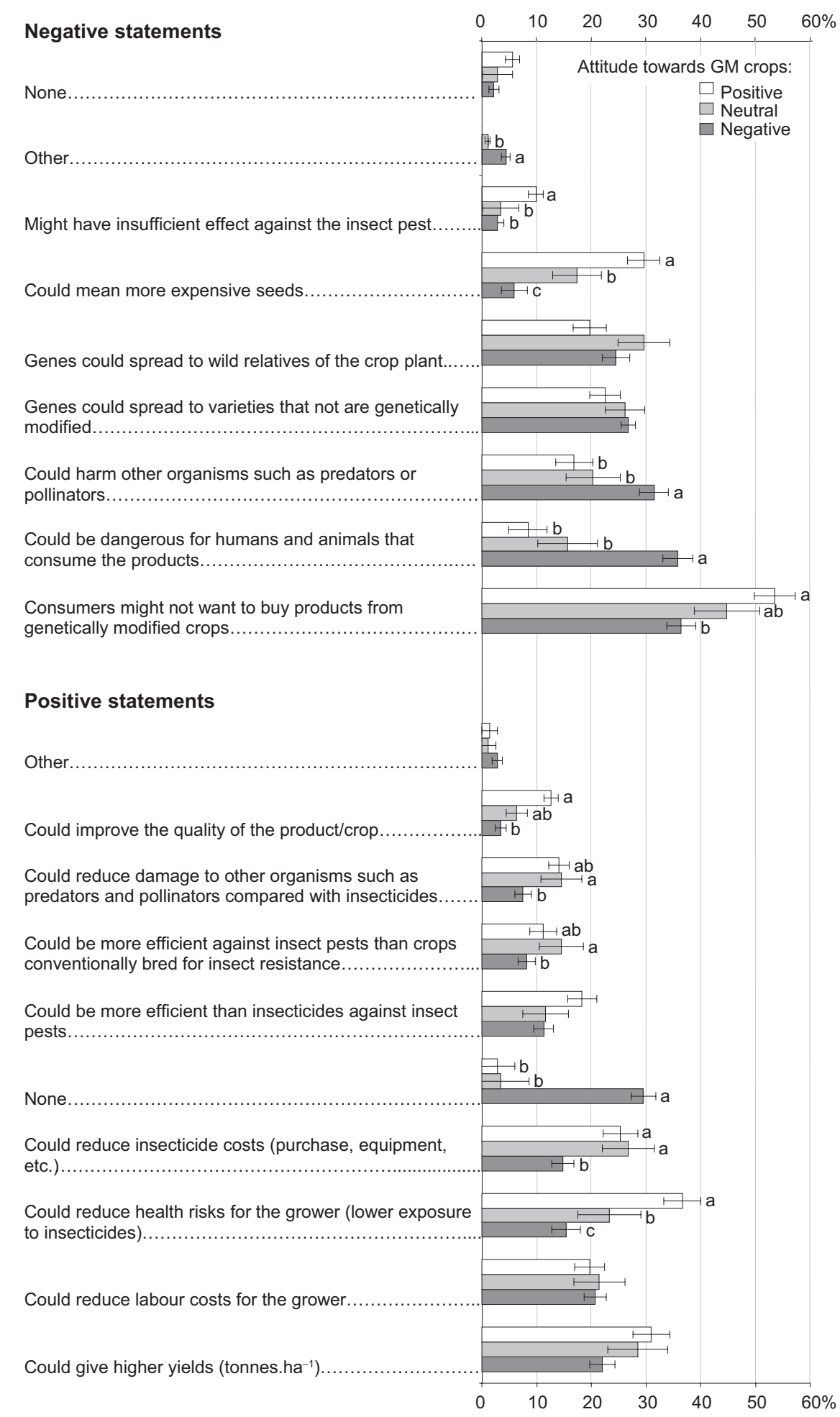

Figure 3. Percentage of farmers positive, neutral or negative towards GM crops, selecting the negative or positive statements (bars showing S.E.). The statements are ordered from least to most frequently selected by all farmers together. Different letters indicate significant differences between groups (Kruskal-Wallis $P<0.05$ ). 


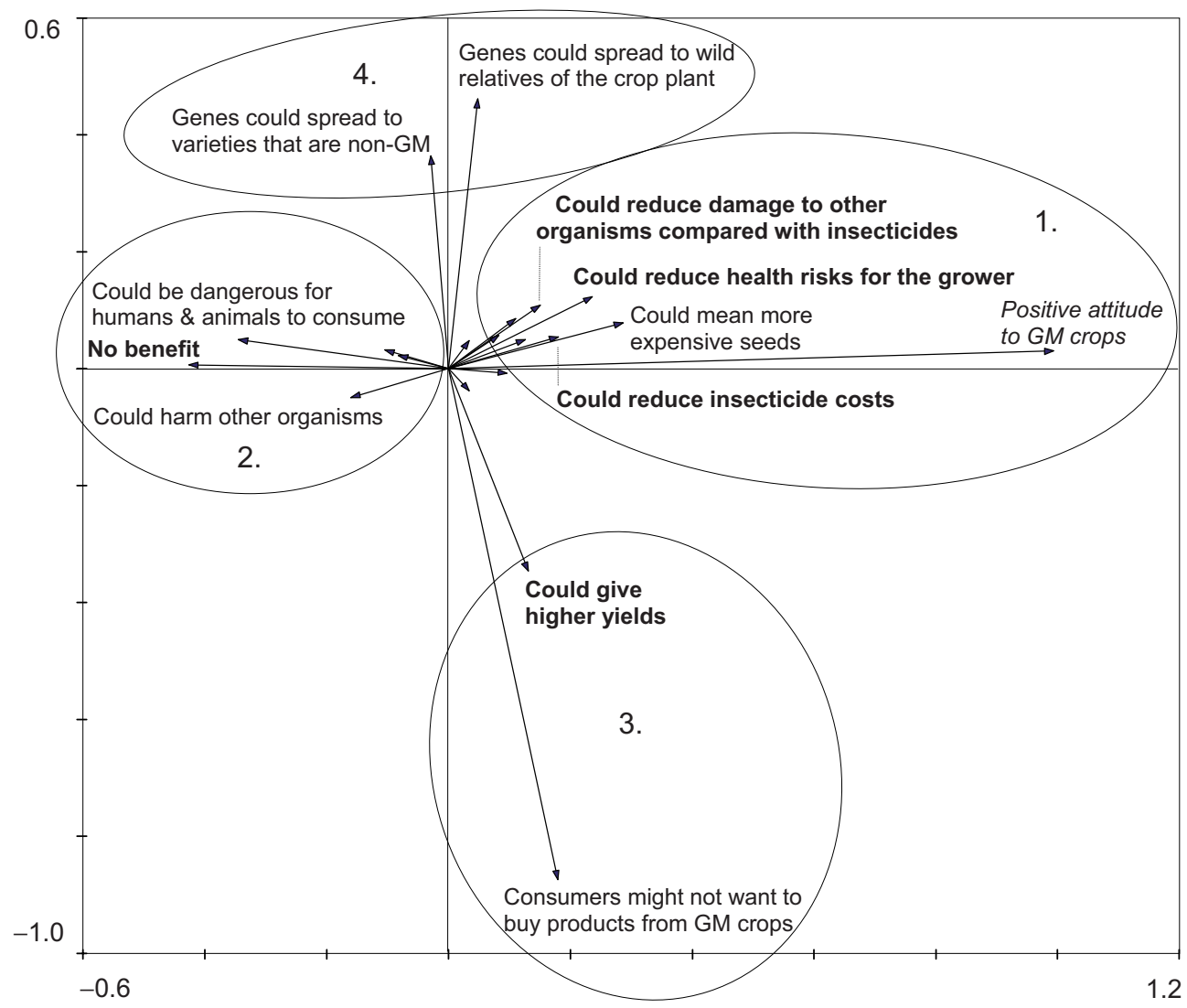

Figure 4. PCA biplot showing the relationship between statements and attitude to GM crops $(n=563$, eigenvalues for axis 1 and 2 was 0.353 and 0.078 respectively). Benefits in bold and drawbacks in normal style.

Table 1. Correlation matrix between statements and attitude to GM crops and two PCA axes with correlation coefficient $>0.10$ (Kendall's tau-b). Eigen values for each component are shown. The largest correlation coefficient for each statement or attitude and PCA axes is indicated in bold. Level of significance indicated by *.

\begin{tabular}{|c|c|c|}
\hline & $P C A 1$ & $P C A 2$ \\
\hline Eigen value & 0.353 & 0.078 \\
\hline Positive attitude to GM crops & $0.856 * * *$ & 0.051 \\
\hline Consumers might not want to buy products from genetically modified crops & $0.205 * * *$ & $-0.695 * * *$ \\
\hline Could be dangerous for humans and animals that consume the products & $-0.345^{* * *}$ & 0.029 \\
\hline Could harm other organisms such as predators or pollinators & $-0.163 * * *$ & -0.054 \\
\hline Genes could spread to varieties that not are genetically modified & -0.012 & $\mathbf{0 . 3 0 3} * * *$ \\
\hline Genes could spread to wild relatives of the crop plant & 0.067 & $0.394 * * *$ \\
\hline Could mean more expensive seeds & $\mathbf{0 . 2 5 5} * * *$ & $0.071 *$ \\
\hline Could give higher yields (tonnes.ha ${ }^{-1}$ ) & $0.133 * * *$ & $-0.284 * * *$ \\
\hline Could reduce health risks for the grower (lower exposure to insecticides) & $0.229 * * *$ & $0.111 * *$ \\
\hline Could reduce insecticide costs (purchase, equipment, etc.) & $\mathbf{0 . 1 7 9} * * *$ & 0.051 \\
\hline No benefits & $-0.416 * * *$ & -0.008 \\
\hline Could reduce damage to other organisms such as predators and pollinators compared with insecticides & $0.146 * * *$ & $0.094 * *$ \\
\hline
\end{tabular}


likely to identify with the agronomic benefits and drawbacks of the crops (Fig. 4; Tab. 1) and unlikely to be concerned about the harm the crops might pose to either humans or livestock. Indeed they perceived the crops to give health benefits for the farmer by reduction in insecticide use. This focus on the agronomic implications of IR GM crops might in part be explained by the correlation between farmers positive to GM crops and large farm size. Although owners of both small and large farms reported economic benefit from the application of GM technology (Gómez-Barbero and Rodríguez-Cerezo, 2006), larger farms tend to use more pesticides (SJV, 2006) and may thereby benefit more from an IR crop. Owners of large farms have also been argued to be early adopters of new agricultural technologies, and thus becomes the major beneficiaries of the new technology (Buttel et al., 1990).

Farmers who expressed a negative attitude towards IR GM crops tended to relate to statements concerned with the potential for the crops to harm both humans and other non-target organisms. They were also unlikely to perceive any benefits generated from IR GM crops, despite reports that not only the seed companies but also consumers and growers have benefited economically from the application of the technology (Fernadez-Cornejo and Caswell, 2006). Calculations on environmental benefits of IR GM crops show both reductions in insecticide usage and $\mathrm{CO}_{2}$ emission by reduced number of insecticide applications (Brookes and Barfoot, 2006). However, those reports have been published in recent years and were probably not available before this survey was made, or may not have filtered through the literature to an information level available to farmers.

Education level enabled distinctions to be made between farmers positive or negative to GM crops, with most positive farmers tending to have higher education in agronomy or rural/farm management while negative farmers did not (Fig. 1). Rural sociologists have found that early adopters of new innovations amongst farmers "tend to be the better-educated, more highly capitalized, more cosmopolitan farmers" (Busch et al., 1989). It should, however, be noted that farm size also seemed to be connected to type of education. The effect on farmers' perception could be a result of either one or a combination of the two. An education in agronomy or likewise provides a level of knowledge and understanding which might not be gained otherwise. It may give a certain level of awareness in relation to new and novel agronomic approaches, which is one of the key aspects in the acceptance of novel technologies (Buttel et al., 1990).

Perhaps the most interesting points appear when considering those farmers who expressed their neutrality towards IR GM crops. These farmers, a little like Poortinga and Pidgeon's 'ambivalent consumers' (2006), seemed to identify with both the benefits and drawbacks associated with IR GM crops. While in most cases they selected the same statements as the positive farmers, they formed neither strong negative or positive opinions. In these cases, none of the drawbacks identified by the neutral farmers singled them out from either of the other two groups, however when considering the benefits, the group identified the potentially positive environmental implications IR GM crops might possess. Frewer et al. (1998) emphasize the importance of effective risk-benefit communication strategies but also point out that improved understanding may polarize attitudes. This suggests that attitudes firmly entrenched one way or the other (positive or negative) are hard to sway, stipulating the need to concentrate on the indecisive or "ambivalent" section of society if aiming to sway opinion. This study has found that just under a third of those surveyed was ambivalent, and therefore could potentially be swayed. Ambivalence is, however, complicated in terms of how attitudes are formulated regarding the balancing of benefits and drawbacks (Poortinga and Pidgeon, 2006). The fact that the neutral group in this study saw potential benefits of IR GM crops, suggests two things: First, it clearly distinguishes them from the negative group who perceived there to be more or less no benefits of IR GM crops, and second, it gives a basis upon which spokesmen for and against GM crops can focus their message.

One further finding of this study is illustrated in the PCA diagram (Fig. 4). It signifies a divergence in opinion of farmers not linked to their attitudes of GM, which suggests that farmers in general, independent of whether they view GM positively negatively or neutrally fall into two categories: those who are concerned with the economic viability of the crops (circle 3 in Fig. 4) and those who are concerned with the effects of gene flow (circle 4 in Fig. 4). The concerns about the risk of transgenic crops interbreeding with non-GM varieties are probably due to the fact that the issue of potential extra costs from co-existence is currently being debated in Europe, and the question of responsibility for eventual economic loss from GM cropping is under consideration in the Swedish government (SOU, 2007). This problem has arisen in the EU partly because of the demand for labeling of products containing more than $0.9 \% \mathrm{GMO}$, leading to potential economic losses for non-GM farmers if transgenes are detected in their harvest. For the GM-farmer there might be increased production costs from preventing spreading the GM trait and in organic production GM is not allowed to be used at all, although the same limit of $0.9 \%$ of accidental presence of authorized GMOs should apply to organic products as well (EU, 2007).

The farmers participating in our survey expressed concerns about market acceptance and environmental risk, as was also found in an earlier survey in 
New Zealand (Cook and Fairweather, 2003). However, the farmers in our study (S) were more negative towards GM crops than their New Zealand (NZ) counterparts (negative: S 57\%/NZ 41\%; positive: S 13\%/NZ 25\%) (Cook and Fairweather, 2003), and this Swedish farmer negativity could be even greater as larger farms, where owners tended to be more positive, were somewhat overrepresented in our study.

What is interesting is the concern Swedish farmers have about consumer acceptance. Numerous studies have shown that about $20 \%$ of the Swedish consumers are reported to be willing to buy GM foods (Fjæstad et al., 2003; Gaskell et al., 2006; Koivisto Hursti et al., 2002 ), which is a greater proportion than the number of positive farmers in our survey (13\%). Currently consumer organisations in Sweden have taken a very negative stance on GM, as have the green groups who campaigned vocally on behalf of the environment and wider society, for example The Swedish Consumer Coalition and Greenpeace (http://www.konsumentsamverkan.se, $\mathrm{http}: / / \mathrm{www}$.greenpeace.org). It is therefore understandable that faced with the hostility towards GM crops, farmers would feel that there is a lack of consumer acceptance for $\mathrm{GM}$ crop production. However the question is whether the vocal minority who has taken a highly negative stance are really representative of the Swedish public as a whole. The point that we would take from this is that currently there is a proportion of farmers who are open to growing IR GM crops in Sweden and the only drawback they see is in terms of consumer acceptance of the crops. If it could be shown that there is a market for GM crops in Sweden, then there is little doubt that these farmers would take the chance to grow IR GM crops commercially.

Using an omnibus survey to gauge farmer's perceptions could have resulted in a low response rate, respondent fatigue and potentially respondent bias, Showever so could many other forms of survey technique employed. What this form of surveying did facilitate was contact with a wide range of farmers across the breadth of Sweden. The high number of respondents was also the reason for choosing closed questions, although disadvantages have been pointed out regarding that form of data collection (Krosnick, 1990).

The findings of this study are not surprising; insecticidal use is generally low in Sweden, so IR traits are perhaps less beneficial here then in other countries. This, however, might change in the wake of climate change, or if IR GM crops are targeted towards specific pests which are prevalent in Sweden. What should be taken from this study is that while the attitude toward GM crops might not be unexpected, the concerns and hopes of Swedish farmers in relation to this technology are highly important if governmental stances on these crops are to be representative of the country's views. Farmers are important
Table 2. Distribution of Swedish farm owners divided by the area of arable land on their farms; the whole population, the farmers taking part in the survey, and actual approved answers.

\begin{tabular}{llll}
\hline \hline $\begin{array}{l}\text { Arable } \\
\text { land }\end{array}$ & $\begin{array}{l}\text { Part of } \\
\text { population }\end{array}$ & $\begin{array}{l}\text { Part of } \\
\text { survey }\end{array}$ & $\begin{array}{l}\text { Approved } \\
\text { answers }\end{array}$ \\
\hline $2-20$ ha & $54 \%$ & $33.3 \%$ & $28.3 \%$ \\
$21-50$ ha & $26 \%$ & $33.3 \%$ & $30.9 \%$ \\
$>51$ ha & $20 \%$ & $33.3 \%$ & $40.8 \%$ \\
\hline
\end{tabular}

stakeholders in the GM debate (Johnson et al., 2007), as the primary consumer of the technology they are affected by any decision made on whether or not a crop can be commercially grown, as they have to compete not only in their national market but on the global market as well.

\section{MATERIALS AND METHODS}

Data were collected by incorporating our three questions in an omnibus survey of Swedish farmers made biannually by Landja Marknadsanalys AB (Åkersberga, Sweden). Questionnaires were sent out on November 3 in 2005 by mail to 1000 farmers with at least 2 ha arable land. The initial mail was followed by two reminder letters and phone calls to retrieve as many answers as possible.

Farmers were selected by dividing the population $(\sim 80000)$ into three classes depending on the size of the farm, 2-20 ha, 21-50 ha and > 50 ha. One third of the total number of farmers receiving the questionnaire (1000) was then randomly selected from each class. This method lead to a higher representation of farmers with large farms than what is representative for the country as a whole, also the percentage of approved (returned correctly filled in) questionnaires was higher from this group (Tab. 2).

To learn about Swedish farmer's attitude to GM crops we asked: "What is your attitude towards genetically modified crops?" Respondents could choose one of the statements: very negative, fairly negative, neutral, fairly positive or very positive. In order to evaluate their expectations and concerns about growing an IR GM-crop they were asked: "There are now plant varieties that have been made resistant to certain insects by genetic modification. What do you think would be the most important disadvantages or drawbacks of growing such crops?" They answered by ticking a maximum of two boxes connected to different statements viewed in Figure 2. In the following question, they where asked to mark two statements of possible positive effects as a reply to the question: "There are now plant varieties that have been made resistant to certain insects by genetic modification. What do you think would be the most important advantages or benefits of growing such crops?" (statements viewed in Fig. 2). In both of these questions, the farmers had the option to fill in another answer under the alternative "other". Individuals selecting more than two alternatives on either of the questions were excluded, leaving 564 individuals 
used in the statistical analyses. The survey also included sociodemographic questions about, age, education, number and kind of animals, hectares of arable land and forest, what kind of crops they grow, and production area.

When testing attitudes among age groups, the farmers were divided in to the following groups, $<35$ years $(n=40), 35-44$ $(n=92), 45-54(n=168), 55-64(n=171)$ and $>64(n=90)$. The actual age was used when investigating correlations of age. Differences between groups divided for example by age or education was tested by Kruskal-Wallis using SAS 9.1 (Cary, NC, USA) statistical package for Windows. A biplot is presented using CANOCO 4.5 for Windows (ter Braak and Smilauer, 2002) in order to visualize the relations between statements (and attitude). A detrended correspondence analysis (DCA) was performed on the selection of statements and attitude towards GM crops to decide whether to use linear or unimodal methods. The length of gradient was 2.813 and subsequently a principal components analysis (PCA) was performed. Correlations between statements (and attitude) and axes were tested with Kendall's tau-b (SAS).

\section{ACKNOWLEDGEMENTS}

The authors thank Jörgen Johansson, Kristoffer Vamling and Inger Åhman for help with formulations of the questions and Robert Glinwood for translation. We are also thankful to Sandra Öberg for help with the statistics and Barbara Ekbom for valuable comments. We also thank the referees for improving this paper. This work was funded by the Swedish Research Council for Environment, Agricultural Sciences and Spatial Planning (FORMAS).

Received January 18, 2008; accepted May 8, 2008.

\section{REFERENCES}

Anderson JC, Wachenheim CJ, Lesch WC (2006) Perceptions of genetically modified and organic foods and processes. AgBioForum 9: 180-194

Brookes G (2007) The benefits of adopting genetically modified, insect resistant (Bt) maize in the European Union (EU): First results from 1998-2006 plantings: PG Economics Ltd

Brookes G, Barfoot P (2006) GM Crops: The first ten years - Global socio-economic and environmental impacts. ISAAA Brief No 36

Busch L, Bonanno A, Lacy WB (1989) Science, technology, and the restructuring of agriculture. Sociol. Rural. 29: 118130

Buttel FH, Larson OF, Gillespie GWJ (1990) The sociology of agriculture. New York, Greenwood Press

Conner AJ, Glare TR, Nap J-P (2003) The release of genetically modified crops into the environment. Part II. Overview of ecological risk assessment. Plant J. 33: 19-46
Cook AJ, Fairweather JR (2003) New Zealand farmer and grower intentions to use gene technology: Results from a resurvey. AgBioForum 6: 120-127

EU (2007) Organic Food: New Regulation to foster the further development of Europe's organic food sector. Press release http://europa.eu/rapid/pressReleasesAction.do?reference= IP/07/807\& format $=$ HTML\&aged $=0$

Fernadez-Cornejo J, Caswell M (2006) The first decade of genetically engineered crops in the United States, Economic information bulletin Number 11. United States Department of Agriculture

Fjæstad B, Olofsson A, Öhman S (2003) Svenskarna och gentekniken - Rapport från 2002 års Europabarometer om bioteknik. Östersund: Mitthögskolan

Frewer LJ, Howard C, Aaron JI (1998) Consumer acceptance of transgenic crops. Pestic. Sci. 52: 388-393

Gaskell G, Allum N, Bauer M, Durant J, Allansdottir A, Bonfadelli H, Boy D, de Cheveigne S, Fjæstad B, Gutteling JM, Hampel J, Jelsoe E, Jesuino JC, Kohring M, Kronberger N, Midden C, Nielsen TH, Przestalski A, Rusanen T, Sakellaris G, Torgersen H, Twardowski T, Wagner W (2000) Biotechnology and the European public. Nat. Biotechnol. 18: 935-938

Gaskell G, Allansdottir A, Allum N, Corchero C, Fischler C, Hampel J, Jackson J, Kronberger N, Mejlgaard N, Revuelta G, Schreiner C, Stares S, Torgersen H, Wagner W (2006) Europeans and Biotechnology in 2005: Patterns and trends. Eurobarometer 64.3. European Commission's Directorate-General for Research

Gómez-Barbero M, Rodríguez-Cerezo E (2006) Economic impact of dominant GM crops worldwide: a review. Luxembourg: European Commission

Hornig Priest S (2000) US public opinion divided over biotechnology? Nat. Biotech. 18: 939-942

James C (2006) Global status of commercialized biotech/GM crops: 2006. ISAAA Brief No. 35. ISAAA: Ithaca, NY

Johnson KL, Raybould AF, Hudson MD, Poppy GM (2007) How does scientific risk assessment of GM crops fit within the wider risk analysis? Trends Plant Sci. 12: 1-5

Koivisto Hursti U-K, Magnusson MK, Algers A (2002) Swedish consumers' opinions about gene technology. $\mathrm{Br}$. Food J. 104: 860-872

Krosnick JA (1990) Survey research. Annu. Rev. Psychol. 50: 537-567

Magnusson MK, Koivisto Hursti U-K (2002) Consumer attitudes towards genetically modified foods. Appetite 39: 9-24

Pilcher CD, Rice ME, Higgins RA, Steffey KL, Hellmich RL, Witkowski J, Calvin D, Ostlie KR, Gray M (2002) Biotechnology and the European corn borer: Measuring historical farmer perceptions and adoption of transgenic Bt corn as a pest management strategy. J. Econ. Entomol. 95: 878-892

Poortinga W, Pidgeon NF (2006) Exploring the structure of attitudes toward genetically modified food. Risk Anal. 26: 1707-1719 
Shelton AM, Zhao JZ, Roush RT (2002) Economic, ecological, food safety, and social consequences of the deployment of Bt transgenic plants. Annu. Rev. Entomol. 47: 845-881

SJV (2006) Yearbook of Agricultural Statistics: Swedish Board of Agriculture

SOU (2007) Ansvarsfrågan vid odling av genmodifierade grödor. Betänkande av utredningen om ansvarsfrågan vid odling av genmodifierade grödor 2007:46. Stockholm: Regeringskansliet

Sveriges Lantbruk (2003) http://abe.dynamicweb.dk/images/ files/Landbrugsundersogelsen.pdf: BioteknikCentrum ter Braak CJF, Smilauer P (2002) CANOCO Reference Manual and CanoDraw for Windows User's Guide: Software for Canonical Community Ordination (Version 4.5). Microcomputer Power, Ithaca, NY, USA

Weaver SA, Morris MC (2005) Risks associated with genetic modification: an annotated bibliography of peer reviewed natural science publications. J. Agric. Environ. Ethics 18: 157189

Wilson TA, Rice ME, Tollefson JJ, Pilcher CD (2005) Transgenic corn for control of the European corn borer and corn rootworms: a survey of Midwestern farmers' practices and perceptions. J. Econ. Entomol. 98: 237-247 